\title{
Petrography of a "cryptic" mixed magma system - the Mount Waldo granite, coastal Maine
}

\author{
D. Gibson ${ }^{1}$, D.R. Lux ${ }^{2}$, AND M.A. ChOATE ${ }^{1}$ \\ 1. Department of Natural Sciences - Geology, University of Maine at Farmington, Preble Hall, 173 High Street, Farmington, Maine, 04938 \\ 2. Department of Earth Sciences, Bryand Global Sciences Building, University of Maine, Orono, Maine, 04369 \\ Date received:December 5, 2003 g Date accepted:April 9, 2004.
}

\begin{abstract}
The Mount Waldo granite (MWG), dated at $371 \pm 2 \mathrm{Ma}$, is typical of the younger Devonian intrusions of the coastal Maine magmatic province. It is a coarse-grained, seriate to porphyritic, biotite \pm hornblende, titanite-bearing granite with abundant intermediate to felsic magmatic enclaves and less abundant mafic schlieren.

The MWG contains feldspars of various textures and composition, including abundant plagioclase-mantled K-feldspar (rapakivi texture), boxy and spongy cellular plagioclase, and plagioclase that show An spikes and/or central cores of higher Ca content. In addition, the magmatic enclaves also preserve textural evidence for mixing and hybridization. Specifically, abundant mafic clots, acicular apatite, inherited megacrysts of all the feldspar varieties common in the host granite, and titanite-plagioclase intergrowths are all observed.

Although very little mafic material is observed in the MWG at its present level of erosion, abundant textural evidence suggests that mixing occurred at depth in this intrusion. The thermal, chemical, and physical gradients initiated by the injection of mafic material produced not only the array of mixing textures observed in the MWG but also the large-scale convection needed to distribute these features throughout the pluton including its highest levels.
\end{abstract}

\section{RÉSUMÉ}

Le granite du mont Waldo (GMW), situé à 371 2 Ma, est caractéristique des intrusions récentes du Dévonien de la province magmatique côtière du Maine. Il s'agit d'un granite titanitifère à gros grain, sérié à porphyrique de biotite \pm hornblende comportant une abondance d'enclaves magmatiques intermédiaires à felsiques et une abondance moindre de schlierens mafiques.

Le GMW renferme des feldspaths de textures et de compositions diverses, notamment une abondance de feldspath potassique recouvert de plagioclase (texture de rapakiwi), de plagioclase alvéolaire massif et spongieux, et de plagioclase présentant des pics d'An ou des noyaux centraux à teneur supérieure en Ca. De plus, les enclaves magmatiques préservent également une preuve texturale de mélange et d'hybridation. On peut, plus précisément observer la totalité de ces traits : une abondance de grumeaux mafiques, de l'apatite aciculaire, des mégacristaux provenant de tous les types de feldspaths courants dans le granite hôte et des enchevêtrements de titanite-plagioclase.

Même si l'on observe très peu de matières mafiques dans le GMW à son niveau actuel d'érosion, d'abondants indices texturaux permettent de supposer que le mixage est survenu en profondeur dans cette intrusion. Les gradients thermiques, chimiques et physiques obtenus par l'injection de matières mafiques a non seulement produit l'éventail de textures de mélange observé dans le GMW, mais également la convection à grande échelle nécessaire à la distribution de ces caractéristiques dans l'ensemble du pluton ainsi qu'à ses niveaux les plus élevés.

[Traduit par la rédaction]

\section{INTRODUCTION}

More than 150 years ago, R.W. Bunsen(1851) first proposed that magmas of contrasting composition could mix to produce a suite of intermediate hybrids. Subsequent research, summarized by Pitcher (1997) and Wilcox (1999), has elevated the status of magma mixing and demonstrated its importance in the evolution of many igneous suites from a variety of magmatic provinces. It has been shown to be a fundamental petrogenetic process in many sub-volcanic environments, often triggering eruption (Murphy et al. 1998; Bachmann et al. 2002), and at deeper crustal levels forming dynamic, open-system magma chambers (Barnes et al. 1986).

The thermal, physical, and compositional gradients that result when mafic and felsic magmas are juxtaposed produce an array of spectacular field relations and a variety of mineralscale disequilibrium textures. Examples are widespread and have been described from the British Tertiary Igneous Province (Harker 1904; Elwell 1958; Wager and Bailey 1953), the Irish Caledonides (Baxter and Feely 2002), and the Sierra Nevada batholith (Reid et al. 1983, 1993; Frost and Mahood 1987). Hibbard $(1991,1995)$ described a number of disequilibrium 


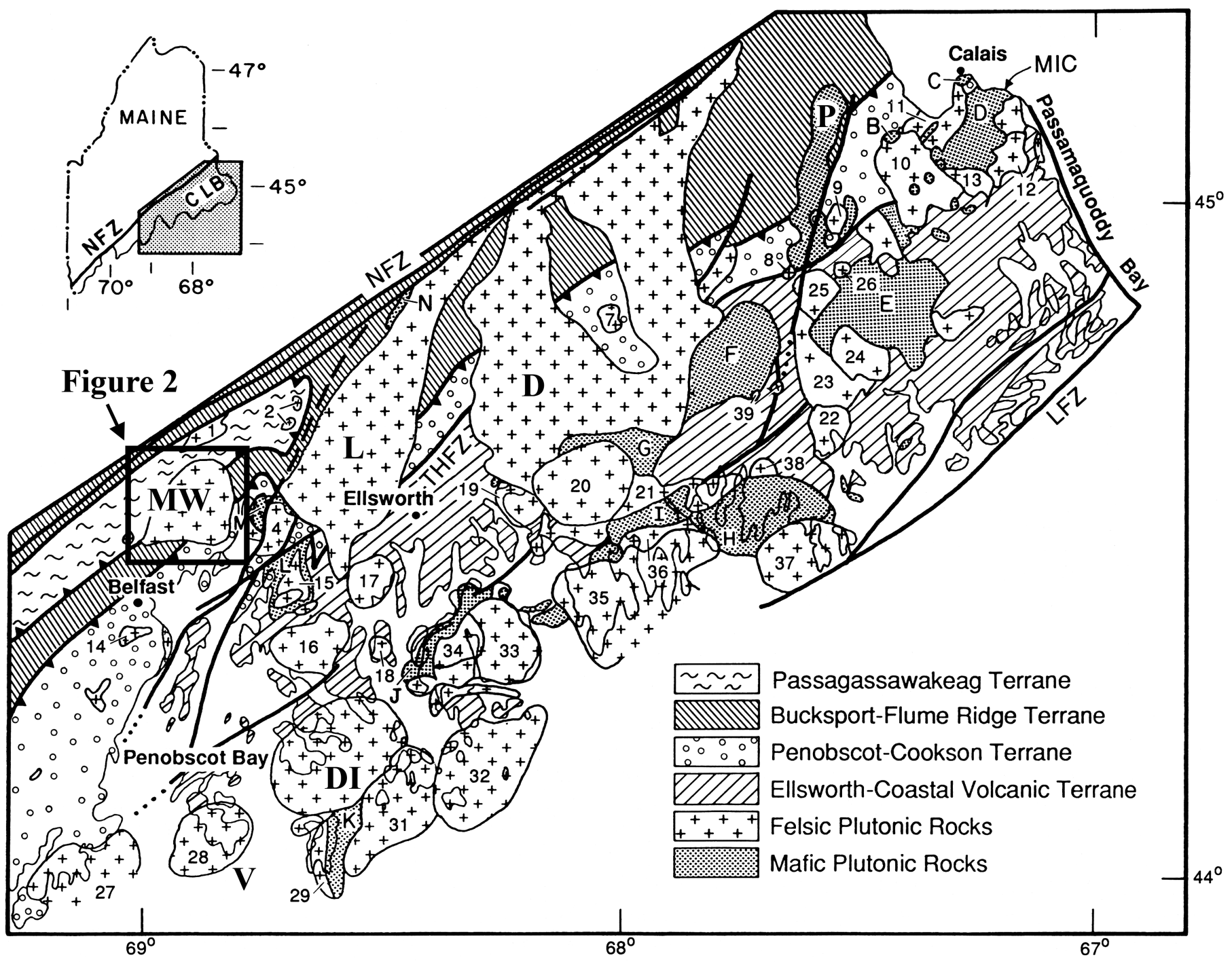

Fig. 1 Simplified geological map of the coastal Maine magmatic province (after Hogan and Sinha 1989) showing the location of the Mount Waldo granite and other intrusions mentioned in the text (MW - Mount Waldo granite; DI - Deer Isle complex; V - Vinalhaven complex; L - Lucerne pluton; D - Deblois pluton; P - Pocomoonshine pluton).

textures produced during magma mixing/hybridization that can be utilized to indicate that coeval mafic and felsic magmas have interacted to varying degrees. In addition, geochemical and isotopic data (Holden et al. 1987; Reid et al. 1983, 1993; Bateman 1995) also have been used to discriminate between magma mixing and other competing magma chamber processes such as fractional crystallization or assimilation.

The coastal Maine magmatic province (CMMP) hosts more than 100 mafic and felsic plutons (Fig. 1). Many of these preserve abundant field and geochemical evidence to indicate that mafic and felsic magmas have interacted extensively (Hogan and Sinha 1989). In these "fossil", high-level magma chambers, such as the Pleasant Bay Complex (Wiebe 1993a), field relations indicate that mafic magma was episodically injected into the crystallizing felsic magma chamber. Evidence for mixing and mingling of coeval magmas has also been preserved in the volcanic sequences of the CMMP such as the Cranberry Island series (Seaman et al. 1995). However, many other plutons of the CMMP, particularly the "younger" Devonian granites (e.g. the Lucerne, Deer Isle, and Mount Waldo plutons, see Fig. 1), lack obvious field evidence that their crystallization was interrupted by episodic injections of mafic magma. In this paper we describe the textural assemblage and crystallization history of the Mount Waldo granite, of which only a $350 \mathrm{~m}$ thick section (most likely toward the top of this intrusion) is currently exposed. We suggest that, even though direct field evidence is lacking, magma mixing played an important role in the evolution of the Mount Waldo pluton. In addition, we discuss the origin of these mingling-related textures in other CMMP intrusions where there is unequivocal evidence for magma mixing/mingling at the present level of erosion. Comparisons between known magma mixing systems and suspected or "cryptic" systems within the same magmatic province could enable us to elucidate magma chamber processes within the 
"younger" granites of the CMMP, even though only their upper structural levels can be examined directly.

\section{REGIONAL GEOLOGY AND THE CMMP}

The coastal Maine lithotectonic block is composed of a series of fault-bounded, NE-trending terranes (Osberg et al. 1985). These peri-Gondwanan terranes were accreted to the Laurentian margin of the North American continent during the Middle Devonian, at the peak of the Acadian orogeny (Stewart et al. 1995; Osberg et al. 1995; Bradley et al. 2000). Emplaced into the coastal block are over 100 post-tectonic intrusions that "stitch" these terranes together. Chapman (1962) first recognized that the coastal Maine plutons form a distinct magmatic province, which he termed the Bays-ofMaine igneous complex. He subdivided this complex into an older phase of layered gabbro and granite and a younger phase of coarse-grained granite, a subdivision that even with new radiometric ages still has some relevance. Hogan and Sinha (1989) re-named the province the coastal Maine magmatic province (CMMP), recognizing that these two phases are petro-tectonically related.

The CMMP is composed of a number of intrusions that are diverse in composition, complexity, and age. They range from gabbro to diorite, and granodiorite to granite, with twomica peraluminous granite also present. Many are composite, zoned intrusions whereas others have crystallized from a single magma batch. The CMMP intrusions range in size from small stocks $\left(<1 \mathrm{~km}^{2}\right)$ to large sub-batholithic bodies $\left(>1500 \mathrm{~km}^{2}\right)$. Hogan and Sinha (1989) subdivided the plutons into four types based on the degree of interaction between mafic and felsic magmas observed within each intrusion as indicated by the abundance of enclaves and composite dikes. The plutons vary in age from Early Silurian (Wenlockian) to Late Devonian (Frasnian), i.e. 425 - $370 \mathrm{Ma}$ (Bradley et al. 2000; Stewart et al. 1995; West et al. 1995). As Chapman (1962) noted, the younger phase is dominated by coarse-grained granite plutons some of which (e.g. the Lucerne and Deblois plutons) form the largest intrusions of the CMMP. Therefore the assembly of the CMMP represented some $50 \mathrm{Ma}$ of crustal recycling, supply of mantle-derived mafic magmas, and a significant volumetric addition to this part of the North American continent.

Wiebe (1993a, b) described a specific category of CMMP intrusion that he named mafic and silicic layered intrusions (MASLI). Examples such as the Pleasant Bay, Cadillac Mountain, and Vinalhaven complexes display compelling field evidence indicating that mafic magmas were injected into, and flowed along the aggrading floors of these felsic magma chambers. Fault block rotation during Mesozoic extension, combined with Cenozoic glaciation, provides almost complete cross sections within these complexes, from their lower replenishment zones to their upper granitic/volcanic carapaces. At lower structural levels there is ample evidence for the injection of mafic magmas with accompanying magma mixing and mingling. Mafic pillow mounds (comparable to pillow basalts), granitic pipes intruding upwards into overlying mafic material, development of hybrid magmas of intermediate composition (that gave rise to enclaves), abundant disequilibrium textures (quartz ocelli and rapakivi feldspar), and large-scale compositional layering are common in the MASLI. Such features suggest that these magma chambers were dynamic, and were fuelled, both thermally and compositionally, by mafic injections.

\section{PETROGRAPHY OF THE MOUNT WALDO GRANITE}

The Mount Waldo granite (MWG) crops out over an area of $\sim 150 \mathrm{~km}^{2}$ at the northern end of Penobscot Bay (Fig. 2). Its contact with the surrounding country rock has been well mapped, along with a $2-3 \mathrm{~km}$ wide andalusite-bearing contact aureole (King 1977; Wones 1991; Stewart 1998). Hornblende geobarometry calculations (Lux et al. 2000) yielded a range of pressures depending on the calibration used: 3.1-3.8 kbars (Hammarstrom and Zen 1986); 3.2-3.9 kbars (Hollister et al. 1987); 3.7-4.3 kbars (Schmidt 1992). Although the results vary, they suggest that the MWG was most likely emplaced at around 3.5 kbars ( $12 \mathrm{kms}$ ). Gravity studies (Sweeney 1976) indicate that the MWG is $<7 \mathrm{~km}$ thick and is a steep-sided, funnel-shaped intrusion. U-Pb zircon data (Stewart et al. 1998) yielded an age of $371 \pm 2 \mathrm{Ma}$, which is in close agreement with the Rb-Sr age of $374 \pm 3 \mathrm{Ma}$ (J.P. Hogan, unpublished data).

The MWG is typically a medium grey, coarse-grained, seriate to porphyritic, biotite \pm hornblende granite with colour index $<15$. It contains abundant large K-feldspar crystals (up to $6 \mathrm{~cm}$ ) many of which, but not all, are mantled with plagioclase to form rapakivi texture. Accessory present minerals are titanite, allanite, zircon, apatite, and magnetite. Minor amounts of molybdenite occur along some joint surfaces (M. Yates, personal communication, 2000). The granite commonly displays a foliation, defined primarily by the feldspar, and to a lesser extent, by biotite. Apart from some minor undulatory extinction in quartz there is little evidence of any solid-state deformation, and we agree with Trefethen (1944) that the foliation is principally magmatic in origin. However, the anisotropy of magnetic susceptibility study of Callahan and Markley (2003) indicated that a small increment of crustal strain occurred during the late stages of crystallization of the MWG.

The petrography of the MWG varies significantly within the pluton and at the outcrop scale. Many parts of the granite are distinctly heterogeneous with variable textures and mineralogy. Two main units of the MWG can be mapped in the field - one, the more typical MWG described above, forms the major part of the intrusion. The other, here termed the Mt. Ephraim unit, consists of granite that is more equigranular in texture and generally lacks the large feldspar crystals that are abundant in the main unit. It has a lower colour index and crops out in the W and NW parts of the pluton. Field relationships between the two units are unclear; however, the Mt. Ephraim equigranular granite is also present as dikes that 


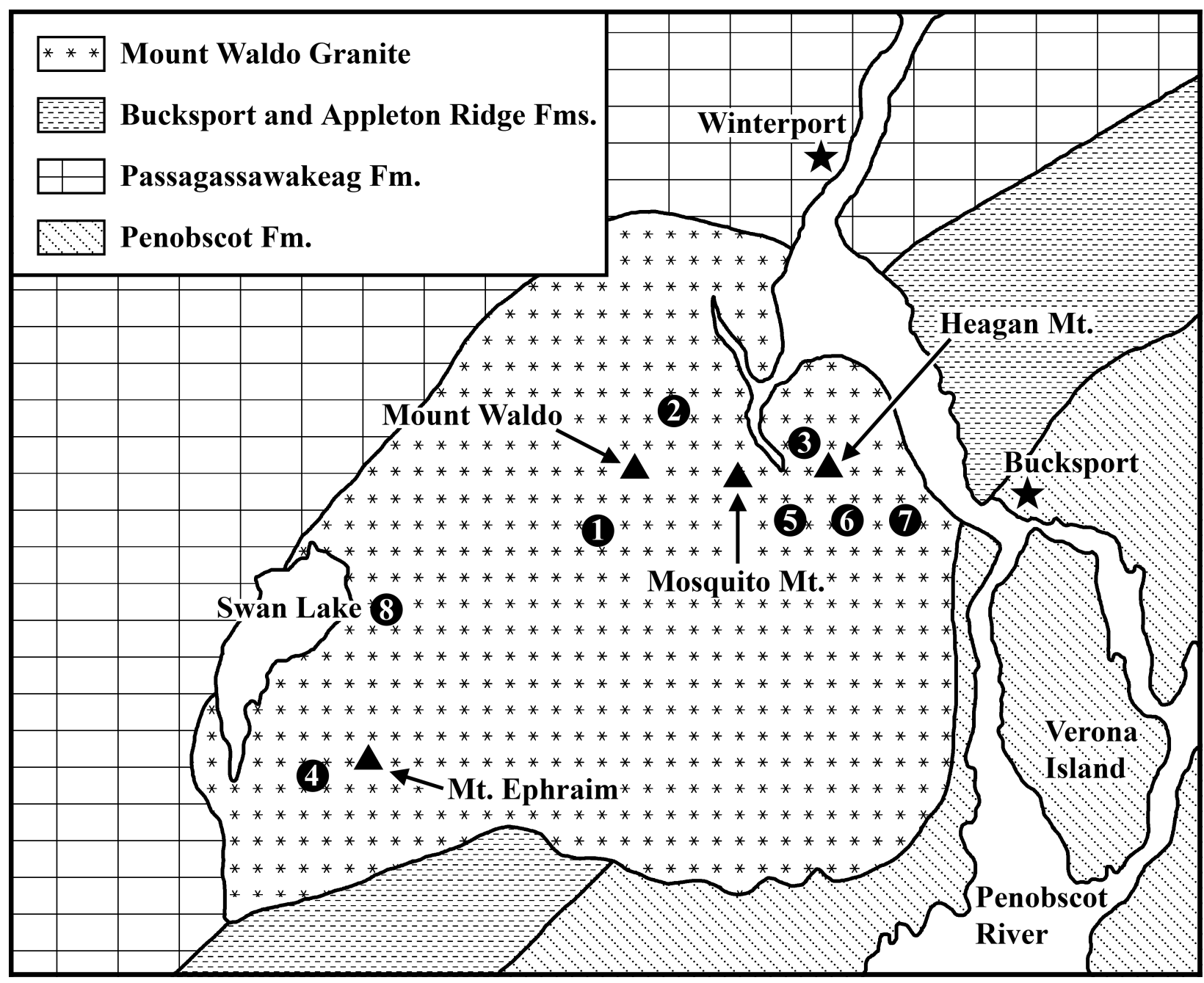

Fig. 2 Sketch map of the Mount Waldo pluton (after Wones 1991 and Stewart 1998), showing the localities where the abundance of rapakivi feldspar was measured.

intrude the main MWG unit, suggesting that it may have been a slightly later pulse.

Smaller scale textural variants, aplites, magmatic enclaves, coarse-grained feldspar domains, and mafic layering or schlieren are also observed in the MWG and contribute to its overall heterogeneous appearance. The enclave suite ranges in composition from quartz diorite, to tonalite and granodiorite, with more leucocratic varieties also common (Gibson et al. 2001). The enclaves have magmatic textures, are typically fine- to medium-grained with equigranular and porphyritic textures, and range in size and morphology from micro-enclaves and mafic clots $(<2 \mathrm{~cm}$ in diameter) to leucocratic enclaves which reach $\sim 1 \mathrm{~m}$ in diameter. The coarse-grained feldspar domains (e.g. Fig. 4b) are composed of many different feldspar varieties (see section 4a below) along with interstitial quartz, and minor amounts of biotite. They commonly enclose enclaves of all compositions and are ubiquitous in the MWG. Similarly, the mafic layering or schlieren occur throughout the pluton. They are mineralogically similar to the granite but have higher concentrations of biotite and hornblende, and up to $12 \%$ acces- sory minerals. They form planar layers, "ladder dikes", trough, and ring structures (Lux and Gibson 2000), and are comparable to layering described in other granitic bodies by Reid $e t$ al. (1993), Wilshire (1969), and Weinberg et al. (2001). These authors attributed the formation of mafic layering to magmatic processes, in particular crystal settling and/or flow segregation. The petrography and field relationships of these textural variants are summarized in Table 1, and modal data (Fig. 3) indicate the wide range of "granitic" compositions evident within the MWG and demonstrate its overall heterogeneity.

In contrast to many other plutons of the CMMP, the MWG lacks appreciable amounts of mafic material at the present level of erosion. In fact, only one mafic dike has been mapped (Trefethen 1944) in the entire intrusion, unlike the other granites of the CMMP such as the Deer Isle Complex, where composite dikes are present. However, the textural/mineralogical assemblage observed in the MWG suggests that mafic magma may have played a more important role in the evolution of this pluton than its absence would seem to imply. 
M

Q

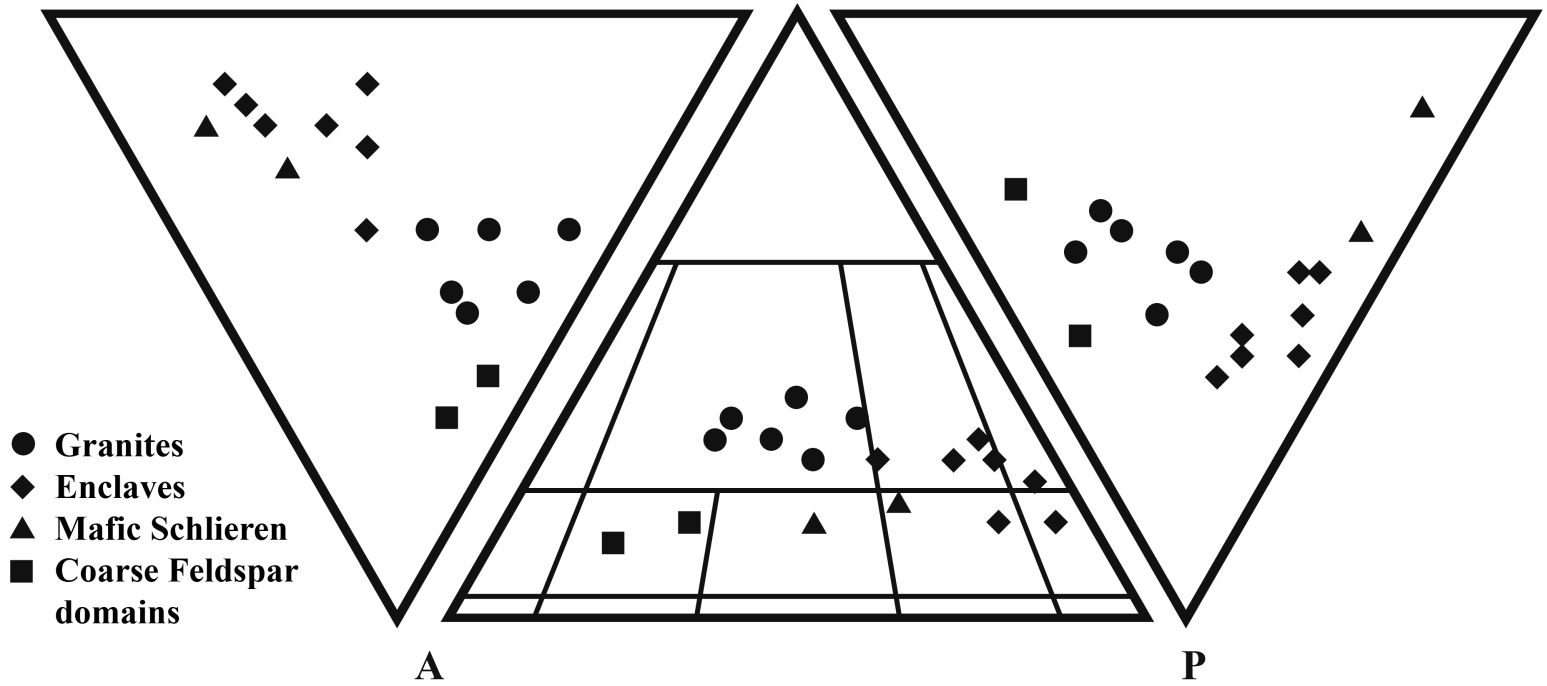

Fig. 3 QAPM modal data for the MWG and its textural variants. Fields on QAP diagram from Streckeisen (1976).
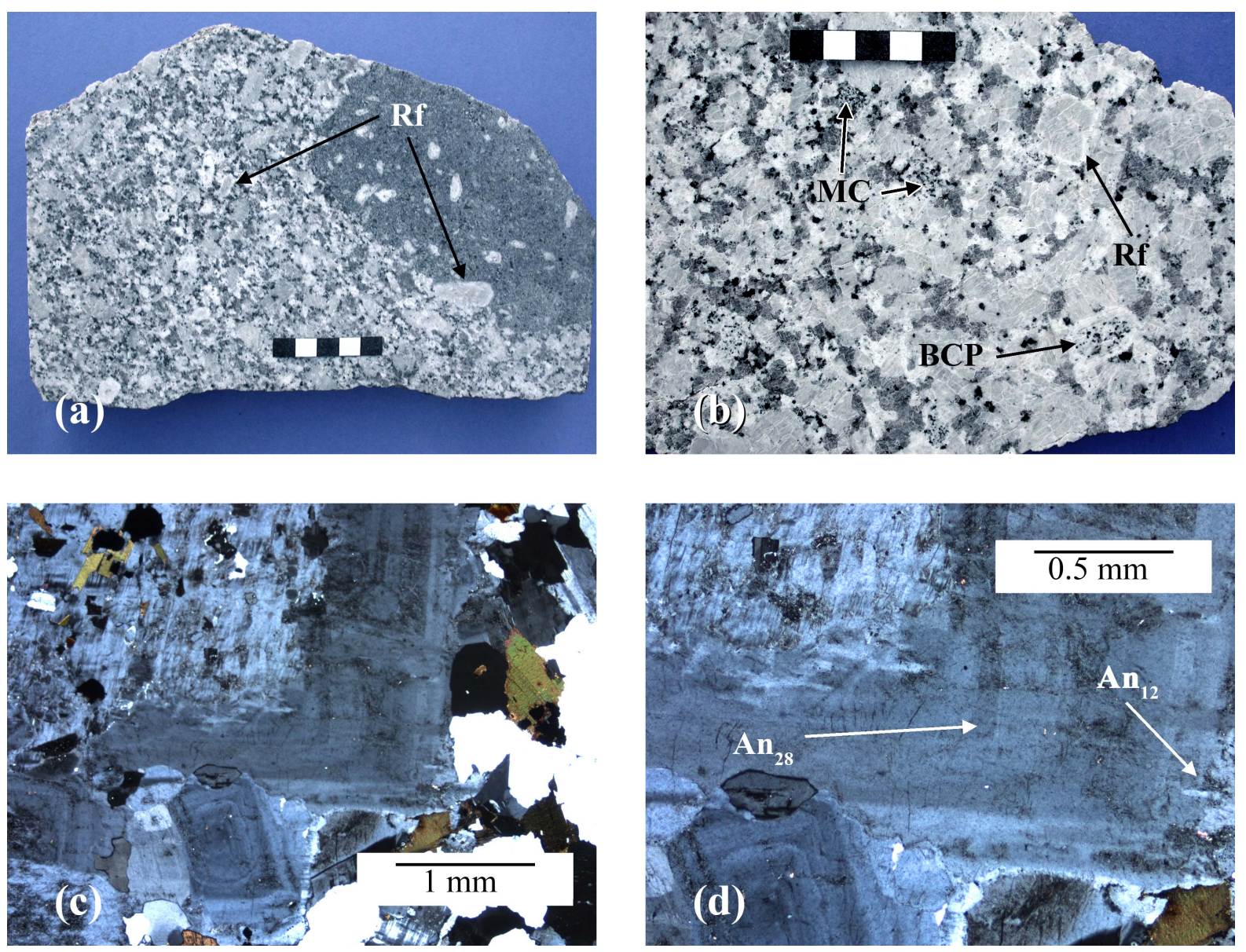

Fig. 4 Rapakivi textures and chemistry in the MWG. (a) Rapakivi feldspar in the MWG and across the boundary between the granite and a leucocratic enclave. (b) Rapakivi feldspar in a coarse-grained feldspar domain along with mafic clots (MC), and a megacryst of boxy cellular plagioclase (BCP). (c) Photomicrograph of rapakivi feldspar illustrating the embayed nature of the K-feldspar grain (sample MWq - 2b). (d) An contents of rapakivi feldspar shown in 4c. 
Table 1. Petrographic summary of the Mount Waldo granite and its textural variants.

\begin{tabular}{|c|c|c|c|c|c|}
\hline Facies & Rock type(s) & Texture and grain size & $\begin{array}{l}\text { Colour } \\
\text { index }\end{array}$ & Mineralogy & Field relations \\
\hline \multicolumn{6}{|l|}{ A) Large-scale units } \\
\hline $\begin{array}{l}\text { Mount Waldo } \\
\text { Granite }\end{array}$ & Feldspar-phyric granite & $\begin{array}{l}\text { Seriate to porphyritic; coarse- } \\
\text { to very coarse-grained }\end{array}$ & $10-15$ & $\begin{array}{l}\text { Qtz, Kf, Pl, Bt, } \pm \\
\text { Amph }\end{array}$ & $\begin{array}{l}\text { Most extensive and typical facies } \\
\text { which forms the major part of the } \\
\text { pluton }\end{array}$ \\
\hline Mount Ephraim unit & Granite & $\begin{array}{l}\text { Equigranular + some } \\
\text { phenocrysts; coarse-grained }\end{array}$ & $<10$ & Qtz, Kf, Pl, Bt & $\begin{array}{l}\text { Crops out in W and NW of the pluton } \\
\text { and forms dykes in the main facies }\end{array}$ \\
\hline \multicolumn{6}{|c|}{ B) Small-scale textural variants } \\
\hline Aplite & Leucogranite & $\begin{array}{l}\text { Equigranular and } \\
\text { saccharoidal; fine-grained }\end{array}$ & $<5$ & $\begin{array}{l}\text { Qtz, Kf, } \mathrm{Pl}, \mathrm{Bt}, \pm \\
\text { tourmaline }\end{array}$ & $\begin{array}{l}\text { Occurs as dykes in many areas; trend } \\
\text { E-W; more than two generations }\end{array}$ \\
\hline Feldspar domains & $\begin{array}{l}\text { Quartz syenite and K- } \\
\text { feldspar-quartz syenite }\end{array}$ & $\begin{array}{l}\text { Euhedral granular; very } \\
\text { coarse-grained }\end{array}$ & $<8$ & $\begin{array}{l}\mathrm{Kf}, \mathrm{Pl}( \pm \mathrm{Rf}, \mathrm{BCP} \text { and } \\
\mathrm{SCP}), \mathrm{Qtz}, \text { minor Bt }\end{array}$ & $\begin{array}{l}\text { Ubiquitous throughout the pluton } \\
\text { and commonly enclose enclaves }\end{array}$ \\
\hline Magmatic enclaves & $\begin{array}{l}\text { Quartz diorite, tonalite, } \\
\text { granite, and granodiorite }\end{array}$ & $\begin{array}{l}\text { Equigranular to porphyritic; } \\
\text { fine- to medium-grained }\end{array}$ & $15-45$ & Pl, Bt, Amph, Kf, Qtz & $\begin{array}{l}\text { Observed throughout the large- and } \\
\text { small-scale variants }\end{array}$ \\
\hline $\begin{array}{l}\text { Mafic layering or } \\
\text { schlieren }\end{array}$ & $\begin{array}{l}\text { Monzonite to quartz } \\
\text { monzonite }\end{array}$ & $\begin{array}{l}\text { Equigranular to porphyritic; } \\
\text { medium-grained }\end{array}$ & $45-60$ & $\begin{array}{l}\mathrm{Bt}, \mathrm{Hb}, \mathrm{Qtz}, \mathrm{Pl}, \mathrm{Kf}+ \\
\text { accessory minerals }\end{array}$ & $\begin{array}{l}\mathrm{Cm} \text {-scale mineral layering observed } \\
\text { throughout the pluton }\end{array}$ \\
\hline
\end{tabular}

Abbreviations: Amph, amphibole; Bt, biotite; Hb, hornblende; Kf, K-feldspar; Pl, plagioclase; Qtz, quartz; Rf, Rapakivi feldspar; BCP, Boxy cellular plagioclase; SCP, Spongy cellular plagioclase.

\section{TEXTURAL ASSEMBLAGE}

A variety of textures, typical of the mixing and mingling of coeval mafic and felsic magmas, are evident at the field and microscopic scales in the MWG including its petrographic variants described above. These textures can be grouped into two categories: a) those pertaining to the feldspar population, and b) those observed in the enclave suite. When considered collectively, these textures suggest that strong thermal, compositional, and physical gradients were operating in the Mount Waldo magma chamber.

\section{Feldspar textures and chemistry}

The feldspar population of the MWG is variable. In addition to the K-feldspar (which includes minor amounts of microcline) + plagioclase assemblage there is a range of disequilibrium feldspar textures, including plagioclase mantles on K-feldspar (rapakivi textures), boxy and spongy cellular plagioclase, complexly zoned plagioclase grains commonly displaying an An "spike", and plagioclase displaying central cored zones. Importantly, these textures are juxtaposed and vary randomly throughout the MWG.

Rapakivi feldspars are ubiquitous in the MWG. They occur as phenocrysts in the granite, enclaves, and mafic schlieren, and as megacrysts in the coarse feldspar domains (Figs. 4a, b). The plagioclase rims are typically narrow zones $1-3 \mathrm{~mm}$ wide, composed either of a continuous epitaxial overgrowth or numerous small grains. The continuous rims are typically zoned, with higher An contents $\left(\sim \mathrm{An}_{28}\right)$ at the contact with the resorbed and embayed K-feldspar, to lower An content $\left(A n_{10-15}\right)$ at the edge of the rim (Figs. $\left.4 \mathrm{c}, \mathrm{d}\right)$. In cases where the rapakivi rim is composed of numerous small plagioclase grains, they are more uniform in composition $\left(\sim \mathrm{An}_{15}\right)$. (Note: All the plagioclase data were collected using a Cameca SX-100 electron microprobe at the University of Maine. The analyses utilized an accelerating voltage of $15 \mathrm{kv}$, beam current of $10^{-9} \mathrm{amps}$ and beam width of $5 \mu \mathrm{m}$. The data was collected on grain traverses or are the average of 5 closely spaced points.)

The abundance of rapakivi feldspars $\left(\mathrm{Rf}\right.$ per $\mathrm{m}^{2}$ ) was measured at a number of localities to assess the overall distribution of this texture in the MWG. Rapakivi feldspars were counted within a $0.25 \mathrm{~m}^{2}$ grid and normalized to $1 \mathrm{~m}^{2}$. At some localities measurements were made at three closely spaced sites, either on horizontal pavement outcrops or, where possible, on three-dimensional surfaces. These localities (Fig. 2) were chosen as representative of the MWG at differing topographic levels and at variable distances from its contact with the country rock. Figure 5 a illustrates that considerable variation occurs at the outcrop scale, with values ranging from $20-80 \mathrm{Rf} / \mathrm{m}^{2}$ at three sites, measured at one locality (\# 3 - Heagan Mountain). Figures $5 \mathrm{~b}$ and $\mathrm{c}$ confirm the lack of any systematic variation of rapakivi feldspar concentration either with elevation or with distance from the margin of the pluton. Hence the MWG contrasts with the Deer Isle Complex where the abundance of rapakivi feldspar varies systematically throughout the Oak 
Point and Stonnington granite units and is a feature used to discriminate between the facies mapped in both granite units of this complex (Hookes 2003).

Numerous plagioclase grains in the MWG display evidence of resorption or dissolution and subsequent re-growth of zones of differing An composition. These processes resulted in the formation of two distinctive plagioclase textures: boxy cellular and spongy cellular plagioclase (Figs. 4b, 6a). Both are common throughout the MWG and consist of $\sim 2 \mathrm{~cm}$ phenocrysts with abundant inclusions of biotite, quartz, and K-feldspar. They are randomly distributed throughout the MWG, like the rapakivi feldspars, and occur in all the textural variants and as phenocrysts in the magmatic enclaves. Hibbard (1995) suggested that boxy cellular plagioclase grains form when plagioclase, originating from the mafic material, comes in contact with the cooler, felsic magma. The plagioclase then becomes converted to more sodic compositions as equilibration occurs. As this process continues, only patches of the original Ca-rich plagioclase remain, isolated in a largely sodic plagioclase grain. A non-cellular rim of sodic composition commonly encloses these grains (Fig. 4b). In contrast, spongy cellular grains are formed when plagioclase from the felsic magma is reheated where it comes in contact with the injected mafic magma (Hibbard 1995). These grains also display non-cellular rims of sodic plagioclase (Fig. 6a).

Plagioclase in the MWG is commonly complexly zoned with a variety of compositional patterns. Lux and Yates (2003) documented these zoning patterns in more detail, and discussed their implications with regard to magma chamber processes. Electron microprobe traverses of plagioclase from the MWG show that many grains display a distinct increase in An content (an An "spike"), which interrupts and/or transects the normally zoned plagioclase. An example from the MWG is shown in Fig. 6b where the An content increases by $\sim 10 \%$ (to $\left.\mathrm{An}_{46}\right)$ compared to the surrounding zones. The An spike zone contains inclusions of biotite, apatite, and quartz with a return to more sodic compositions $\left(\mathrm{An}_{15}\right)$ outwards to the edge of the grain. An spikes have been described previously by numerous workers, including Wiebe (1968) and Baxter and Feely (2002), and they attributed this texture to magma mixing processes. They proposed that An spikes are caused by the introduction of plagioclase grains into more mafic, Ca-rich magma proximal to the mafic-felsic interface at lower levels in a hybridizing magma chamber. The return to more sodic compositions could be a result of either equilibration of the plagioclase with surrounding melt as it, in turn, hybridizes, or recycling of the grain back to the more felsic part of the magma chamber.

Other plagioclase grains have distinct cores of higher An content (of andesine composition), which are commonly seriticized (Fig. 6c). These grains have been interpreted as inherited grains from the mafic magma or alternatively as restite crystals (White and Chappell 1977). However, the fact that these plagioclase varieties all occur together might imply that they originated in disparate parts of a compositionally heterogeneous magma chamber and were transported through the chamber by convection.
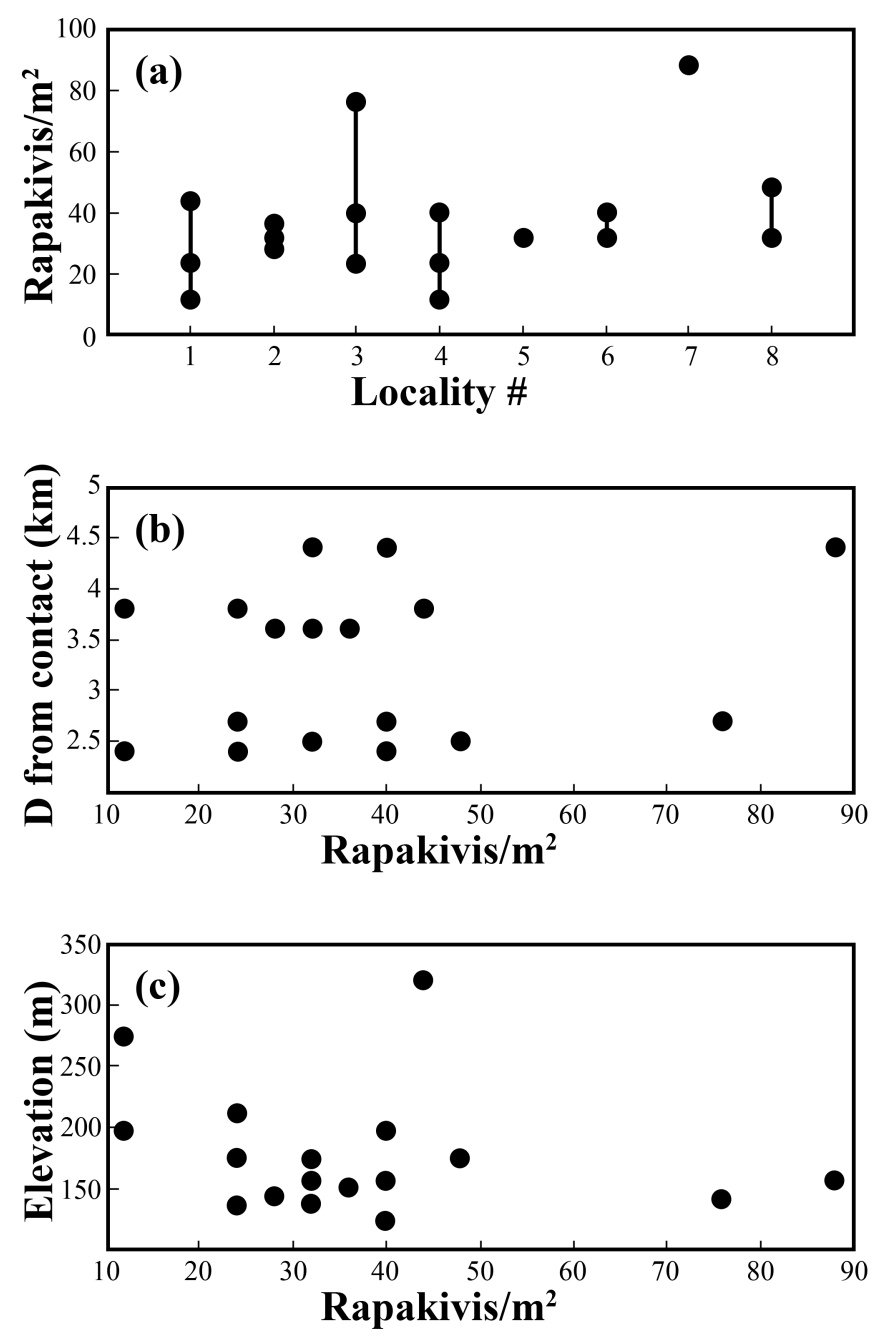

Fig. 5 Distribution of rapakivi feldspar $\left(\mathrm{Rf} / \mathrm{m}^{2}\right)$ within the MWG. (a) Rf $/ \mathrm{m}^{2}$ at each locality (see fig. 2). (b) Distance from outer contact versus $R f / \mathrm{m}^{2}$. (c) Elevation versus $R f / \mathrm{m}^{2}$.

\section{Enclave textures}

The enclaves observed in the MWG have a variety of textures which are often attributed to mixing and mingling processes. Some of these textures are more common in the mafic -intermediate enclaves whereas others are observed in all types. Of note are micro-enclaves or mafic clots, feldspar phenocrysts observed in the magmatic enclaves, apatite morphology, and intergrowths of plagioclase and titanite.

Mafic clots concentrations of biotite, hornblende, quartz, and feldspar (Figs. 4b, 6d) are ubiquitous throughout the MWG. In some examples, hornblende rims enclose pyroxene cores of diopside composition, indicating a reaction texture. Their formation is problematic as they could be either small fragments of disaggregated enclave material, or small globules of the mafic end-member.

Most of the magmatic enclaves, independent of their composition, are porphyritic with a variety of feldspar phenocrysts, including K-feldspar, plagioclase, and feldspars with 

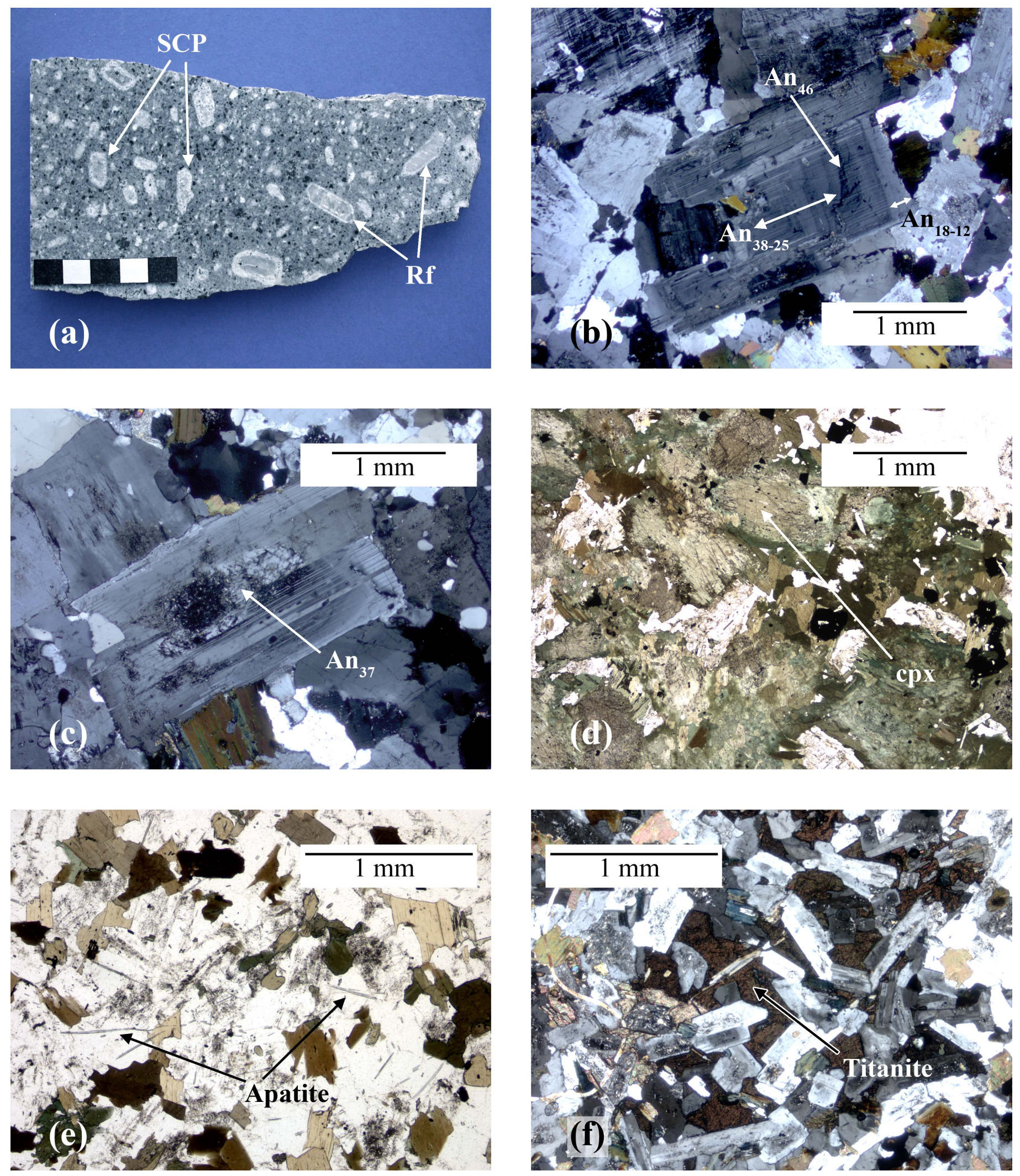

Fig. 6 Mixing textures in the MWG. (a) Spongy cellular plagioclase (SCP) along with rapakivi feldspars (Rf) in a leucocratic enclave. (b) Anorthite spike in plagioclase (sample MWq-2b). (c) Plagioclase with seriticised, high An core also from sample MWq-2b. (d) Mafic clot in MWG, with hornblende rim on a pyroxene. (e) Acicular apatite in quartz-diorite enclave. (f) Ophitic to sub-ophitic intergrowth of titanite and plagioclase in quartz diorite enclave. 
the disequilibrium textures described above (rapakivi feldspar, boxy and spongy cellular plagioclase). Therefore, the enclaves commonly have exactly the same feldspar population as the host granite. These "phenocrysts" are the classic "dent des cheval" described from many calc-alkaline granitoids (Pitcher 1997). The consensus of opinion suggests that they are not phenocrysts sensu stricto, but rather formed by the mechanical entrainment of crystals during hybridization (Vernon 1986, 1991). They could be considered more correctly as inherited megacrysts. The fact that the feldspars are observed in the enclaves and across the host-enclave boundary has been cited as evidence of their entrapment during transportation of grains in a convecting magma chamber (Hibbard 1995).

Apatite is a common accessory mineral throughout the MWG and is particularly abundant in the mafic schlieren where it is observed as euhedral prismatic crystals. However, in the quartz diorite and tonalite enclaves it is typically acicular in shape with high aspect ratios (Fig. 6e). Wyllie et al. (1962) suggested that this morphology is a quench texture, formed by the rapid cooling of mafic globules when they came in contact with cooler, felsic magma.

Titanite ocelli (referred to as sphene-centered ocelli by Hibbard 1995) consist of titanite in ophitic intergrowth with plagioclase, surrounded by a felsic zone consisting of K-feldspar + quartz + plagioclase. It is a feature common to many mixed magma systems (Baxter and Feely 2002), including, in the CMMP, the Deer Isle (Hookes 2003) and Vinalhaven complexes where it is observed in many mafic enclaves. It is, however, rare in the MWG, but an associated texture, ophitic to sub-ophitic intergrowths of titanite and plagioclase laths without the felsic haloes, is observed in many quartz diorite and tonalite enclaves (Fig. 6f). This texture is closely related to the formation of titanite ocelli and implies that the enclave was once in a Ti-rich environment, i.e. mafic magma. This intergrowth could be an intermediate stage in the formation of titanite ocelli (see Fig. 19.3 in Hibbard 1995) where the titanite-plagioclase "clot" remains within the enclave rather than forming the quartz/feldspar rim of true titanite ocelli, where it comes in contact with the more felsic magma.

\section{CRYSTALLIZATION HISTORY OF THE MWG}

The assemblage of textures described above, along with field relations observed in the MWG, indicate a definite role for the mixing and mingling of disparate magmas (Hibbard 1981) and the formation of hybrids as represented by the enclave suite. Many of the feldspar textures indicate they were formed in two stages. The dissolution textures suggest that initially, re-heating resorbed the grains. Subsequently, re-growth occurred where there was a supply of material of differing composition to form the overgrowth rims. However, comparable textures have been ascribed also to decompression associated with magma ascent and eruption (Cherry and Trembath 1978; Nekvasil 1991). Importantly, in the MWG feldspars with variable textures are observed commonly juxtaposed in the same hand sample or thin section (see Figs. 4c, 6b, 6c).

The feldspar population of the MWG consists of K-feldspar, rapakivi feldspar, and plagioclase phenocrysts alongside boxy/spongy cellular plagioclase and variably zoned plagioclase grains. The latter, typically with resorbed, high An cores, are observed alongside weakly zoned crystals. No systematic variation of this feldspar population has been recognized with structural level or position in the Mount Waldo intrusion. However, if these textures had originated by a decompression event, some systematic variation should be evident. A decompression origin would also require two populations of crystals - those that were present before decompression and those that crystallized afterwards. It is also difficult to explain the mixture of inherited phenocrysts within the magmatic enclaves and across the host/enclave contact (Fig. 6a) by a decompression event. If the $\mathrm{T}$ and $\mathrm{P}$ conditions (or $\Delta \mathrm{T}$ and $\Delta \mathrm{P})$ were similar, then plagioclase zonation should be consistent for each grain.

Evidence from other MASLI-style intrusions of the CMMP suggests that the mixing/mingling textures were formed deeper in the magma chamber, adjacent to the mafic input zones. In the Vinalhaven intrusion, hybrid magmas of intermediate composition developed and exhibit a wide range of disequilibrium textures in the zone of mixing and mingling between the mafic and felsic layers. Rapakivi feldspars are much more abundant (nearly every grain has a plagioclase mantle), as are resorbed quartz and titanite occelli, suggesting that they originated there. The hybrid rocks developed are texturally, mineralogically, and compositionally similar to enclaves found in the higher, granitic portions of this intrusion (Lux et al. 2001). The distribution of these textures within this pluton suggests that once mafic input occurred, mixing textures were formed and subsequently distributed around the magma chamber by convection. The latter was probably initiated (and possibly maintained) by the thermal shock of mafic magmas intruding the crystallizing felsic chamber. Mafic magmas are much hotter than felsic magmas and this heat is dispersed as cooling and crystallization progresses. In the MWG mixing/mingling textures were formed at the interface between these disparate magmas and then circulated throughout the chamber resulting in the variable feldspar population and mixture of plagioclase types within the same sample. This process was also responsible for the distribution of enclaves. Feldspar megacrysts may have been incorporated in the enclaves at the time of their formation or later as they both circulated through the chamber.

Once mixing in the system was initiated, it became an autocatalytic process due to the thermal, chemical, and physical gradients set up in the magma chamber and their subsequent effects on the body of the magma chamber by convection. These gradients perpetuated themselves throughout the chamber and were responsible for the highly variable nature of the MWG. Textural variants such as the coarse feldspar domains (Table 1 and Fig. 4b), possibly initially cumulate layers, were subsequently disrupted and transported through the chamber, collecting enclaves of variable composition. As a result, 
the higher level of the pluton could have been a complex mix of crystallizing framework and passageways of magma flow creating the conditions, i.e., flow segregation and/or crystal settling, conducive for the formation of the mafic schlieren.

In conclusion, MASLI-style magma chambers were common in the early stages of the development of the CMMP. However, the younger Devonian plutons, here exemplified by the MWG, may also have crystallized in dynamic, hybrid magma chambers as implied from complex the feldspar population and enclave textures described here. These plutons are in effect "cryptic" MASLI, where the body of evidence points to mixing as an important process in their evolution, although the actual mixing zone cannot be observed at the current erosional levels. Additional whole-rock and mineral geochemistry along with isotopic data will enable us to critically test this model, and to evaluate the extent of the involvement of mafic magmas in the generation and crystallization of granitic rocks in the CMMP.

\section{ACKNOWLEDGEMENTS}

This work was funded by National Science Foundation grants EAR 0003694 and 0003660 awarded to DG and DL respectively. MC thanks the Student Research Fund at the University of Maine at Farmington for additional funding for summer fieldwork. We thank Dr. Martin Yates (University of Maine) for his extensive and invaluable help with the electron microprobe component of this study and Stacey Hodges (UMF) for her patience and expertise with the figures. Comments by the journal reviewers, Sheila Seaman and David Bailey, were very helpful and greatly improved the manuscript.

\section{REFERENCES}

Bachmann, O., Dungan, M.A., \& Lipman, P.W. 2002. The Fish Canyon magma body, San Juan Volcanic field: Rejuvenation and eruption of an upper crustal batholith. Journal of Petrology, 43, pp. 1469-1503.

Barnes, C.G., Allen, C.M., \& SAleeby, J.B. 1986. Open- and closed-system characteristics of a tilted plutonic system, Klamath Mountains, California. Journal of Geophysical Research, 91, no. B6, pp. 6073-6090.

Bateman, R. 1995. The interplay between crystallization, replenishment and hybridization in large felsic magma chambers. Earth Science Reviews, 39, pp. 91-106.

Baxter, S., \& Feely, M. 2002. Magma mixing and mingling textures in granitoids: examples from the Galway granite, Connemara, Ireland. Mineralogy and Petrology, 76, pp. 63-74.

Bradley, D.C., Tucker, R.D., Lux, D.R., Harris, A.G., \& McGregor, D.C. 2000. Migration of the Acadian Orogen and Foreland Basin across the Northern Appalachians. U.S. Geological Survey Professional Paper, No. 1624.

Bunsen R.W. 1851. Über die Processe der vulkanischen Geste- inbildungen Islands. Ann. Phys. Chem. (Dritte Reihe), 83, pp. 197-272.

Callahan, C.N., \& Markley, M.J. 2003. A record of crustalscale stress: igneous foliation and lineation $\mathrm{n}$ the Mount Waldo Pluton, Waldo County, Maine. Journal of Structural Geology, 25, pp. 541-555.

Chapman, C.A. 1962. Bays-of-Maine igneous complex. Geological Society of America Bulletin, 73, pp. 883-888.

Cherry, M.E., \& Trembath, L.T. 1978. The pressure quench formation of rapakivi texture. Contributions to Mineralogy and Petrology, 68, pp. 1-6.

ELWeLl, R.W.D. 1958. Granophyre and hybrid pipes in dolerite layer of Slieve Gullion. Journal of Geology, 66, pp. 57-71.

Frost, T.P., \& Mahood, G.A. 1987. Field, chemical, and physical constraints on mafic-felsic magma interaction in the Lamarck Granodiorite, Sierra Nevada, California. Geological Society of America Bulletin, 99, pp. 272-291.

Gibson, D., Lux, D.R., \& Hogan, J.P. 2001. Geochemistry of enclaves and schlieren from the Mt. Waldo pluton, Maine: Implications for magma chamber processes. Geological Society of America NE section annual meeting, abstracts with programs, 33, $68 \mathrm{p}$.

Hammerstrom, J.M., \& Zen, E-An. 1986. Aluminum in hornblende: an empirical igneous geobarometer. American Mineralogist, 71, pp. 1297-1313.

HARKer, A. 1904. The Tertiary igneous rocks of Skye. Memoir of the Geological Survey of Scotland, $481 \mathrm{p}$.

HibBaRd, M.J. 1981. The magma mixing origin of mantled feldspars. Contributions to Mineralogy and Petrology, 76, pp. $158-170$.

Hibbard, M.J. 1991. Textural anatomy of twelve magmamixed granitoid systems. In Enclaves and Granite Petrology, Developments in Petrology 13, Edited by J. Didier and B. Barbarin. Elsevier, Amsterdam, pp. 431-443.

Hibbard, M.J. 1995. Petrography to Petrogenesis. Prentice Hall, New Jersey, 587 p.

Hogan, J.P., \& SinHa, S.K. 1989. Compositional variation of plutonism in the coastal Maine magmatic province: mode of origin and tectonic setting. In Studies in Maine Geology, v. 4: Igneous and Metamorphic Geology. Edited by R.D. Tucker and R.G. Marvinney. pp. 1-44.

Holden, P., Halliday, A.N., \& Stephens, W.E. 1987. Neodymium and strontium isotope content of microdiorite enclaves point to mantle input to granite production. Nature, 330, pp. 53-56.

Hollister L.S., Grissom, G.C., Peters, E.K., Stowell, H.H., \& Sisson, V.B. 1987. Confirmation of the empirical correlation of $\mathrm{Al}$ in hornblende with pressure of solidification of calc-alkaline plutons. American Mineralogist, 72, pp. 231-239.

Hookes, B.P. 2003. Petrology of the Deer Isle pluton, coastal Maine: A complex mixed magma system. MS thesis, University of Maine, $185 \mathrm{p}$.

KING, A.W. 1977. The petrology and geochemistry of the 
Mount Waldo granite, southeastern Maine. MS thesis, University of Maine at Orono. $79 \mathrm{p}$.

Lux, D.R., \& Gibson, D. 2000. Magmatic structures within the Mt. Waldo granite, Maine. Geological Society of America (NE section annual meeting), Abstracts with program, $\mathrm{p}$. 32.

Lux, D.R., Gibson, D., Hogan, J.P., \& Johnson, B. 2000. Petrologic variation and magmatic structures in plutons of Penobscot Bay area, Maine. In Guidebook to field trips in coastal and east-central Maine: New England Intercollegiate Geologic Conference, $92^{\text {nd }}$ annual meeting. Edited by M.G. Yates, D.R. Lux and J.T. Kelley, pp. 208-223.

Lux, D.R., Gibson, D. \& Hogan, J.P. 2002. Thermal convection in silicic magma chambers: Evidence from the Coastal Maine Magmatic Province. In, $18^{\text {th }}$ General meeting of teh International Mineralogical Association, abstracts with program, p. 258.

Lux, D.R., \& Yates, M.G. 2003. Reading the plagioclase record. Geological Society of America (NE section annual meeting), abstracts with program, 35, p. 36.

Murphy, M.D., Sparks, R.S.J., Barclay, J., Carroll, M.R., Lejeune, A-M., Brewer, T.S., Macdonald, R., Black, S., \& YounG, S. 1998. The role of magma mixing in triggering the current eruption at the Soufriere Hills volcano, Montserrat, West Indies. Geophysical Research Letters, 25, pp. 3433-3436.

NeKvasil, H. 1991. Ascent of felsic magmas and formation of rapakivi. American Minerlaogist, 76, pp. 1279-1290.

Osberg, P.H., Hussey, A.M. II, \& Boone, G.M. 1985. Bedrock geologic map of Maine: Maine Geological Survey, Augusta, ME; Scale 1:500 000.

Osberg, P.H., Tucker, R.D. AND Berry, H.N. 1995. Is the Acadian suture lost? In Guidebook to field trips in southern Maine and adjacent New Hampshire: New England Intercollegiate Geologic Conference, $87^{\text {th }}$ annual meeting. Edited by A.M. Hussy and R.A. Johnson, pp. 145-172.

PITcher, W.S. 1997. The nature and origin of granite (second edition). Chapman \& Hall (publishers), London, $387 \mathrm{p}$.

Reid, J.B., Evans, O.C., \& Fates, D.G. 1983. Magma mixing in granitic rocks of the central Sierra Nevada, California. Earth and Planetary Science Letters, 66, pp. 243-261.

Reid, J.B., Murray, D.P., Hermes, O.D., \& Steig, E.J. 1993. Fractional crystallization in granites of the Sierra Nevada: How important is it? Geology, 21, pp. 587-590.

Schmidt, M.W. 1992. Amphibole composition in tonalite as a function of pressure: an experimental calibration of the Al-in-hornblende barometer. Contributions to Mineralogy and Petrology, 110 (23), pp. 304-310.

Seaman, S.J., Wobus, R.A., Wiebe, R.A., Lubick, N., \& BowRING, R.A. 1995. Volcanic expression of bimodal magmatism: The Cranberry Island-Cadillac Mountain complex, coastal Maine. Journal of Geology, 103, pp. 301-311.

Stewart, D.B. 1998. Geology of Northern Penobscot Bay, Maine. Miscellaneous Investigations Series Map I-2551.

Stewart, D.B., Tucker, R.D., \& West, D.P., Jr. 1995. Genesis of Silurian composite terrane in northern Penobscot Bay,
Maine. In Guidebook for field trips in southern Maine and adjacent New Hampshire: New England Intercollegiate Geological Conference, 87th annual meeting; Edited by A.M. Hussy and R.A. Johnson, pp. A3-1 - A3-21.

Streckeisen, A.L. 1976. To each plutonic rock its proper name. Earth Science Reviews, 12, pp. 1-33.

SwEENEY, J.F. 1976. Subsurface distribution of granitic rocks, south-central Maine. Geological Society of America Bulletin, 87, pp. 241-249.

Trefethen, J.M. 1944. Mt. Waldo Batholith and associated igneous rocks, Waldo County, Maine. Geological Society of America Bulletin, 55, pp. 895-904.

VERNON, R.H. 1986. K-feldspar megacrysts in granites - phenocrsysts not porphyroblasts. Earth Science reviews, 23, pp. 1-63.

VERNON, R.H. 1991. Interpretation of microstructures of microgranular enclaves. In Enclaves and Granite Petrology, Developments in Petrology 13. Edited by J. Didier and B. Barbarin. Elsevier, Amsterdam, pp. 277-292.

WAGER, L.R., \& BAILEY E.B. 1953. Basic magma chilled against acid magma. Nature, 172, pp. 68-69.

Weinberg, R.F., Sial, A.N., \& Pessoa, R.R. 2001. Magma flow within the Tavares pluton, northeastern Brazil: Compositional and thermal convection. Geological Society of America Bulletin, 113, pp. 508-520.

West, D.P. JR., GuidotTi, C.V., \& Lux, D.R. 1995. Silurian Orogenesis in the Western Penobscot Bay Region, Maine. Canadian Journal of Earth Sciences, 32, pp. 1845-1858.

White, A.J.R., \& ChAppell, B.W. 1977. Ultrametamorphism and granitoid genesis. Tectonophysics, 43, pp. 7-22.

WiEbE, R.A. 1968. Plagioclase stratigraphy: a record of magmatic conditions and events in a granite stock. American Journal of Science, 266, pp. 690-703.

Wiebe, R.A. 1993a. The Pleasant Bay layered gabbro-diorite, coastal Maine: ponding and crystallization of basaltic injections into a silicic magma chamber. Journal of Petrology, 34, pp. 461-489.

WIEBE, R.A. 1993b. Basaltic injections into floored silicic magma chambers. EOS, Transactions, American Geophysical Union, 74, pp. 1-3.

Wones, D.R. 1991. Bedrock geologic map of the Bucksport quadrangle Waldo, Hancock, and Penobscot counties, Maine. USGS Map GQ-1692.

WiLcox, R.E. 1999. The idea of magma mixing: history of a struggle for acceptance. Journal of Geology, 107, pp. 421432.

WiLshire, H.G. 1969. Mineral layering in the Twin Lakes granodiorite, Colorado. Geological Society of America Memoir, 115, pp. 235-261.

Wyllie, P.J., Cox, K.G., \& Biggar, G.M. 1962. The habit of apatite in synthetic systems and igneous rocks. Journal of Petrology, 3, pp. 238-243.

Editorial responsibility: Sandra M. Barr 
